\title{
Integration Level of Social Environmental Disclosure (SED) Between The Global Reporting Initiative(GRI)- Sustainability Reporting and The International Integrated Reporting Council (IIRC) Reporting Among European Companies
}

\author{
Suzila Mohamed Yusof, Nazaria Md Aris and Nurul Syuhada Zaidi \\ Faculty of Economics and Business, Universiti Malaysia Sarawak (UNIMAS)
}

\begin{abstract}
This critical approach study examines the social and environmental disclosure (SED) between Sustainability Reporting (SR) and Integrated Reporting (IR) among European companies. The research question is to examine the integration level of SED within SR and IR. Applying the critical text analysis method, the GRI G3 guidelines were used to examine a sample of ten European companies. The reports for the selected companies must incorporate fully applied IR without producing any more SR in order to analyse the validity of the data. This study has discovered that there is less integration of SED in IR than SR. It is apparent that the IR approach is more towards the primary groups (investors) rather than other stakeholders, society and the environment as a whole. Hence, IR is only a mirror of sustainability for business strategy. Therefore, IR needs to engage reports with other stakeholders to sustain long-term growth.
\end{abstract}

Keywords: social and environmental disclosure; sustainability reporting; integrated reporting; global reporting initiative, IIRC

\section{INTRODUCTION}

Reporting on sustainability has developed significantly in the past three decades (Stubbs and Higgins, 2014). Especially in the recent ten years, there has been a momentous rise in SR amongst large multinational companies (Kolk, 2010). SR creates SED and brings great improvement of the quality of reports focusing on the Triple Bottom Line (TBL); social, environmental and financial disclosure (Bebbington, Unerman and O'Dwyer, 2014). There are, additionally, worries that SR may have been 'caught' by organisations trying to increase hegemonic/dominance power (accaglobal, 2012). The conviction that the preparation of corporate reporting on sustainability resulted from an exploration in social and environmental reporting can possibly effect on and transform corporate conduct (Bebbington and Gray, 2001). However, this sentiment usually may unable to achieve (Bebbington and Gray, 2001). Notwithstanding the important and late development in SR, the most recent confirmation concluded that almost all the world's largest 250 companies report on Corporate Responsibility (CR) and that 'Reporting is now the norm across all these sectors, with at least $62 \%$ of companies in every sector producing a CR report' (GRI, 2015). SED brings new channels of communication to influence the public. Through filling of the legitimacy gap (Archel et al., 2009) and increase legitimacy gap (Bouten et al.2011), SED delivers a positive image to companies and expands financial reporting (Bebbington, Unerman and O'Dwyer, 2014). Types of the disclosure include parts of annual reports, stand- alone reports, press releases and corporate websites (Bebbington, Unerman and O'Dwyer, 2014). Companies attempt to convince society that they have stakeholders' interest at heart 
and that they share common goals by using SED in social and environmental reporting as legitimising mechanism of companies to its stakeholders (Deegan et al., 2000; Deegan, 2002, 2007; and Mathews, 2004). Development of SED has been influenced by the arrival of IR in 2010. IR contains about organization's plan, governance, performance and prospects in a brief delivery report, for its external environment through the value creation for short, medium and long-term (IIRC, 2013). IR merges SED and financial reports in a single report (de Villiers et al, 2014). As centralization of reports is important for most companies, several studies made by academics showed some weaknesses in them (de Villiers et al., 2014).SR concentrates more on a narrative and as such they cannot be directed by financial reports (Bebbington et al., 2014). Therefore, this study explores the integration level of SED when moving from SR to IR.

\section{Research Questions and Design}

This study aims to search on how does the measurement of integration of SED, moving from SR to IR. In order to respond to the purpose of the study, small samples can be analysed to find distinctive research perspectives (Fairclough 2003). Additionally, the gathering of data from small samples is applicable as generalisation in order to show the population (Fairclough, 2003). Analysis of SR and IR is undertaken by deep reading and reviewing the reports of ten selected companies, interpretatively taking out elements of social and environmental information. The content of SED in the reports was analysed using a simple measurement. Instead of measuring using simple calculation, it highlights the development of SED in reports and checkups the spread or scope of SED throughout the reports. The process of measurement is being executed by considering the sections of each report that reported on social and environmental information, for example, the chairman's statement, risk management, corporate governance review and business review. It generates an image of analysis by an adequate link between the social and environmental information and therefore, integration between them can be effectively recognised. This measurement adopts the GRI G3 guidelines (Table 4) as indicators to evaluate the results. In the analysis, measurement of SED is being done when the positive relationship occurred between the total number of elements and the integration level. When the total number of elements is increasing, it shows that the integration level is also the same. Eventually, using the approach undertaken in the analysis, several measurements have been calculated as follows:

- Accumulation difference overtime (ADOT) measures the total change (expand/diminish) in the number of sections in the reports reviewed where each element of social and environmental information appears.

- Proportion of positive difference of a number of sections measures the proportion of elements in each category (social and environmental) that are reported in an increased number of sections over the period.

- Proportion of positive and no difference of a number of sections measure the proportion of elements in each category (social and environmental) that are reported in an increased and no change in number of sections over the period.

\section{Sample Selection}

Ten samples of ten European companies (refer to Table 1) are relevant in this study by reviewing all SR and IR since representing high social and environmental impact. These selected companies have been chosen with the condition that the companies must have fully implemented IR without producing any more SR. Although most European companies have established sustainability in their businesses, the analysis undertaken by the IIRC (integratedreporting.org) indicates that only ten percent of companies have disclosed non-financial information in their reports. This shows that there is still a lack of reporting disclosures engaging in the reports. 


\section{Reliability and Validity of Data}

In this study, the process of deep reading and reviewing the data and analysis contributes to the reliability of the research as reliability is replaced by repeatability (Merkl-Davies et al., 2011). All the SR and IR needs to be analysed using the process of close reading the information content in the reports, especially the content related to social and environmental sections. Gathering of information will be recorded using the GRI G3 guidelines. Critical text analysis is relevant for using small samples of data in order to establish the reliability of data (Merkl-Davies et al., 2011). With regard to this study, ten company samples are reliable in order to obtain high reliability of data. Regarding validity, this evaluates how data or information should be measured (Okpara and Idowu, 2013). In order to evaluate the validity, this study takes into consideration companies that had already applied SR and started changing to IR immediately. Critical text analysis is valid in this study as it does not rely on 'scientific method' and thus does not follow a rigid set of procedures (Merkl-Davies et al., 2011). Consequently, there is a relatively high degree of validity in this study.

Table 1: Summary of Sample of Companies

\begin{tabular}{|l|l|l|l|}
\hline Company & Industry & $\begin{array}{l}\text { Year of } \\
\text { SR }\end{array}$ & $\begin{array}{l}\text { Year of } \\
\text { IR }\end{array}$ \\
\hline Deutsche Borse Group & Construction Services & 2011 & 2012 \\
\hline ENBW & Electricity Energy & 2011 & 2012 \\
\hline Grupa Lotos, Poland & Oil and Gas & 2008 & 2009 \\
\hline Indra Spain Hotel & Teurism & 2007 & 2008 \\
\hline $\begin{array}{l}\text { Melia International } \\
\text { Munich Airport }\end{array}$ & Transportation & 2012 & 2013 \\
\hline $\begin{array}{l}\text { Novo } \\
\text { Denmark }\end{array}$ & Healthcare & 2003 & 2004 \\
\hline Royal BAM Group & Construction Services & 2013 & 2014 \\
\hline Royal DSM & $\begin{array}{l}\text { Life and material } \\
\text { sciences }\end{array}$ & 2009 & 2010 \\
\hline Uralsib & Financial Services & 2010 & 2011 \\
\hline
\end{tabular}




\section{LITERATURE REVIEW}

\section{Social Environmental Disclosures (SED)}

SED practices are intended to legitimise business organisations and develop strategies of legitimating (Archel et al., 2009). The existence of SED is explained by the emergence of legitimacy theory (LT) on the interaction between social value and acceptable behaviour of organisations (Dowling and Pfeffer, 1975). LT is defined by de Aguiar and Bebbington (2014) as a strategic way for an organisation to disclose good news and convince stakeholders to repair damaged legitimacy using certain legitimacy strategies. For example, SED has been used as a legitimating purpose in the CEO statements of SR. Despite expanding the standardisation of SR, the statements pinpoint management impression rather than accountability (Barkemeyer et al., 2014). The degree to which corporate SR serves as a reasonable representation of corporate sustainability-related performance involves drawing a similarity with financial reporting (Barkemeyer et al., 2014). Patten (2014) suggests that, in order to make SED a corporate legitimacy, it should become a tool of the public interest in the form of stand-alone reports rather than mandatory reports. SED helps to manipulate social perceptions of environmental aspects by showing consistent beliefs and contributions (de Aguiar and Bebbington, 2014). However, according to Patten (2014), the practices of SED do not form the main agenda for obtaining high profit levels, as SED is more concerned with nurturing the image of environmental concern rather than catering for environmental actions. Additionally, environmental reporting has been developed to 'thicken the veil' (Patten, 2014, p. 201), covering environmental impact rather than transparency for the public interest.

\section{GRI Guidelines}

Of all the standards that are available, the GRI guidelines are the most influential guidelines adopted by various organisations in preparing SR (Gomes et al., 2015), aiming to establish a generally accepted framework (Bebbington et al., 2014). The GRI guidelines target on the TBL by analysing information that is applicable and material to organisations for stakeholder's interest (GRI, 2013). The analysis finds that 78 percent of the best 100 organizations within 41 nations and 82 percent of the highest ranking within 250 organizations from the Global Fortune 500 use these guidelines (Gomes et al., 2015). GRI was established in 1997 and have been formally published since 2000 by the Coalition for Environmentally Responsible Economies (CERES) and the United Nations Environmental Programme (UNEP) (Isaksson and Steimle, 2009). The significant operator embedded within GRI guidelines enhances the quality of SR (Kolk and Perego, 2010; Perego and Kolk, 2012) and engaging most stakeholders, including the community and environment (Gray et al., 2014). This study applies the GRI-G3 guidelines, which were launched in 2006 (Levy et al., 2006). This version of the guidelines comprises principles and guidance in portraying the quality and content SR as well as setting report boundaries (Isaksson and Steimle, 2009). The guidelines lay down organisational profile, governance processes and structures, and administration of sustainability issues incorporate all performance indicators of goals and social, environmental and economic (Isaksson and Steimle, 2009).

\section{Sustainability Reporting (SR)}

SR focuses on much wider attention and is intended to inform several different groups of stakeholders (Busco et al., 2013). As pointed out above, this challenges the usefulness of SR and stresses the role of materiality as to prioritize the needs of all stakeholders. SR is voluntary, with the exception of some countries, and exists in the context of a continuingly evolving situation (Busco et al., 2013). As SR is most widely employed standards for disclosure, the scope of SR goes beyond the legal entity and the assurance level is low, in the sense that non-financial information is more challenging to assure compared to financial information (Busco et al., 2013). Lodhia (2014) has highlighted that SR is a new strand of accounting and a relatively new phenomenon which recognises social and environmental 
issues as critical and needs to be communicated effectively to stakeholders. The benchmark to measure a sustainable society can be divided into 'strong' and 'weak' criteria (Monfreda et al., 2004). Strong sustainability assumes that natural capital irreplaceable and essential for example air and water; whilst weak sustainability builds when assets total is preserved within the human well-being (Monfreda et al., 2004). In terms of natural capital, it is very difficult to maintain rather than weak sustainability as when environmental and ecological services being destroyed, technology may be capable of restoring it (Monfreda et al., 2004). Strong sustainability can be related with the environmental impacts. The analysis of the banks past reports by Lodhia (2014) indicates that it defines its environmental risks as both direct and indirect (Lodhia, 2014). Direct environmental risks include the usage of the natural resource, emissions and waste generation, whilst indirect environmental risks occur through the financial products and services offered, suppliers and partnerships (Lodhia, 2014).

\section{Integrated Reporting (IR)}

IIRC introduces a pilot program that monitors the implementation of IR whereby the early implementation exists during the period between 2009 to 2012 (Ioana \& Adriana, 2013). The pilot program offers to companies to demonstrate global leadership in the field of corporate reporting (unepfi.org). It involves companies as well as investors with the support of IIRC and peer group feedback from other participants (unepfi.org). IR objectives to furnish a concise report that demonstrates an organisation's social, environmental and economic actions, risks, outcomes and opportunities to reflect the integration of an organisation in terms of measurement and management (de Villiers et al., 2014). However, most academics researchers justify the implementation of IR. McNair Connolly et al., (2013) argue that IR systems are view in two perspectives: for their support of management decision-making processes and as strategic information sources for annual IR. On the other hand, Serafeim (2014) explores the connection between IR and the structure of a firm's investor base. The study theorises that organisations which practise IR have more long-term investor bases and commitment and less transient investors. Stubbs and Higgins (2014, p. 1070) argue that IR is not conferred as the next generation of SR. Yet, IR acts as an endeavour to encourage a more efficient and cohesive way to deal with corporate reporting that draws on distinctive reporting strands. In turn, IR functions to act only those that material for in the scope of short, medium and long- term (Stubbs \& Higgins, 2014). Furthermore, Brown and Dillard (2014) suggest 'broadening up' and 'opening up' of sustainability perspectives in IR by using a participatory approach that promotes engagement. Brown and Dillard (2014) argue that IR, as perceived by IIRC offers a strict and report the content on sustainability issues in a biased way. In turn, IR remains practically as a closed approach that reflects only for business practices (Brown \& Dillard, 2014). The effectiveness of the engagement procedure relies on the framing process, which permits reflection on conflicting views, prompting to social change (Brown and Dillard, 2014). Additionally, Flower (2015) argues that, based on the IIRC framework, the IIRC has forgotten sustainability accounting. It bases this conclusion on the notion that the IIRC's concept of value is 'value for investors' and not 'value for society' (Flower, 2015, p. 1). Flower (2015) states that IR has failed to deliver, which can be traced to a division in the IIRC organisation between idealists (advocates of social and environmental accounting) and realists (representatives of the accountancy profession, preparers (notably multinational enterprises) and regulators). The approach to improve IR raise by Adams and Simnett (2011) by planning to show how IR gives an opportunity to all associations to take part in all-encompassing, valuable and important reporting thinking inside an association, and may subsequently help catalyse behavioural change inside associations.

\section{Differences between SR and IR}

The difference between SR and IR can be distinguished by the capital terms. As for IR, the IIRC states that only capitals that are important and relevant to the organizations to be classified as capitals (IIRC, 2013), thus allowing for a fix application of the framework. However, Busco et al (2013) argue 
that IR is not able to measure the stocks for the six capitals and their variations (flows). For some capitals, IR only measures some specific aspects, employing such indicators as a proxy for the whole capital (Busco et al., 2013). Clearly, outcomes are much more difficult to measure; this may be a further evolution and one of the main challenges IR will have to face (Busco et al., 2013). While IR takes into account the measurement (in terms of stock and flow) of capitals, which have clear similarities with balance sheets and income statements respectively, SRs report on the impacts of company activities (Busco et al., 2013). Conversely, SRs, the approach of natural capital (Monfreda et al., 2004) is significant in the reports concerning the environment impacts either direct or indirect impacts (Lodhia, 2014). Another scholar mentions the distinct idea of the differences between these two. IIRC develops 'capital' concept while the GRI develops the concept of 'stakeholders' (Busco et al., 2013). The elements proposed by the GRI are in fact divided by aspect, thus into categories that are clearly inspired by different stakeholders' groups (economic, environmental, social, human rights, product responsibility, etc.) (Busco et al., 2013). Additionally, SR and IR may be distinguished in many aspects (Table 2) (drcaroladams.net, integratedreporting.org, globalreporting.org and theguardian.com).

Table 2: Comparison between SR and IR

\begin{tabular}{|l|c|c|}
\hline Components & Sustainability Reporting (SR) & $\begin{array}{c}\text { Integrated Reporting } \\
\text { (IR) }\end{array}$ \\
\hline Primary Audience & Stakeholders & Shareholders \\
\hline Main Focus & $\begin{array}{c}\text { Measuring impacts (value } \\
\text { protection) }\end{array}$ & $\begin{array}{c}\text { Value Creation }- \\
\text { short, medium and }\end{array}$ \\
\hline Perspectives & Backward -Looking & Forward Looking \\
\hline Capitals & Natural Capital & Multiple Capitals \\
\hline Material Principle & $\begin{array}{l}\text { Aspects that should be covered: } \\
\text { Organisation significant } \\
\text { impacts } \\
\text { : social, environmental } \\
\text { and economic or } \\
\text { Control elements for } \\
\text { decision- making and }\end{array}$ & $\begin{array}{c}\text { Organisations } \\
\text { capality to create } \\
\text { value by } \\
\text { changing the } \\
\text { assessments of } \\
\text { financial capital } \\
\text { providers }\end{array}$ \\
\hline
\end{tabular}

\section{RESEARCH METHODOLOGY}

This study adopts a primarily interpretative or critical approach to analyse the content of SR and, immediately, the introduction of IR. In this approach, there are three forms of textual analysis to be distinguished (Merkl-Davies et al., 2011), starting with the scientific analysis involved in the positivist research methodological approach; for example, calculating sentences, words, coding and paragraphs and moving to 'interpretative text analysis' and 'critical text analysis' (Merkl-Davies et al., 2011). As both Global Reporting (GRI) - SR and IIRC - IR represent significant SED, this study compares the results from conducting critical text analysis and measuring the extent of reporting. Specifically, as critical text analysis approach does not adopt positive scientific research, it does not abide by fix arrangement of procedures (Merkl-Davies et al., 2011). Additionally, according to Merkl-Davies et al. (2011), critical text analysis, from the social constructivist paradigm, aims to comprehend and explain organisational actors' definitions of reality. Social constructivist approaches consider corporate narrative documents as intentions to establish and sustain relations of domination (Milne et al., 2009). Such approaches also aim to understand how preparers of reports use corporate narratives for sense-making identity construction and legitimation (Demers et al., 2003). 


\section{DISCUSSION AND FINDINGS}

The summary (Table 3) concludes the total ADOT (accumulation difference overtime) score for each company in terms of social and environmental aspects, including the proportion positive difference and the proportion positive and no difference in the social and environment sections. In terms of the ADOT of the social aspect, this has shown that only three of ten companies increased disclosure in IR. Most of the companies disclosed around 70 percent fewer elements of social aspect in IR. On the other hand, ADOT for the environmental aspect showed that only four companies increased their environmental disclosure and only one company had no change in environmental disclosure. A justification for the lower score is because most companies have just introduced IR as new reporting and are still trying to adopt IR. Furthermore, the reports were combined with financial information and therefore, companies tried to balance between financial and sustainability/non-financial information. In addition, the table shows that the proportion of the positive difference in social elements ranges from 0 percent to 48 percent. The justification of these results presents that companies responded to social issues for more than half of the report content instead of limiting the reporting to financial information. However, the social content represents minor parts of the report instead of other elements such as risk and governance, financial and business scopes. In the aspect of environmental information, the measures range from 0 percent to 43 percent of elements, showing a positive difference in the number of sections where they are presented. This scenario is similar to social elements as the range incurred is almost the same. The percentage shows that fewer environmental elements are reported and disclosed in IR. It seems that companies focused on other sections during the integration as more information needs to be disclosed in one particular report. This study also shows the percentage of elements in the number of sections for positive and no difference, where the interpretation further indicates the deficiency of negative change: in very few scenarios, SED were disclosed in fewer sections as IR has been introduced.

Table 3: Summary of the Sample Companies Measuring the Integration Level

\begin{tabular}{|c|c|c|c|c|c|}
\hline No & Company & Industry & & $\begin{array}{l}\text { Social } \\
\text { Aspects }\end{array}$ & $\begin{array}{l}\text { Environ. } \\
\text { Aspect }\end{array}$ \\
\hline \multirow[t]{3}{*}{1} & \multirow{3}{*}{$\begin{array}{l}\text { Deutsche Borse } \\
\text { Group }\end{array}$} & \multirow{3}{*}{$\begin{array}{l}\text { Construction } \\
\text { Services }\end{array}$} & Total ADOT & +18 & 0 \\
\hline & & & $\begin{array}{l}\text { Proportion of positive } \\
\text { difference in number of }\end{array}$ & $48 \%$ & $40 \%$ \\
\hline & & & $\begin{array}{l}\text { Proportion of positive and no } \\
\text { difference in number of section }\end{array}$ & $88 \%$ & $77 \%$ \\
\hline \multirow[t]{3}{*}{2} & \multirow[t]{3}{*}{ ENBW } & \multirow[t]{3}{*}{ Electricity Energy } & Total ADOT & -20 & -22 \\
\hline & & & $\begin{array}{l}\text { Proportion of positive } \\
\text { difference in number of section }\end{array}$ & $10 \%$ & $0 \%$ \\
\hline & & & $\begin{array}{l}\text { Proportion of positive and no } \\
\text { difference in number of section }\end{array}$ & $65 \%$ & $50 \%$ \\
\hline \multirow[t]{3}{*}{3} & \multirow[t]{3}{*}{ GrupaLotos } & \multirow[t]{3}{*}{ Oil and Gas } & Total ADOT & -11 & -1 \\
\hline & & & $\begin{array}{l}\text { Proportion of positive } \\
\text { difference in number of section }\end{array}$ & $0 \%$ & $3 \%$ \\
\hline & & & $\begin{array}{l}\text { Proportion of positive and no } \\
\text { difference in number of section }\end{array}$ & $73 \%$ & $93 \%$ \\
\hline \multirow[t]{3}{*}{4} & \multirow{3}{*}{ Indra } & \multirow{3}{*}{$\begin{array}{l}\text { Telecommunicatio } \\
\text { ns }\end{array}$} & Total ADOT & -7 & -14 \\
\hline & & & $\begin{array}{l}\text { Proportion of positive } \\
\text { difference in number of section }\end{array}$ & $18 \%$ & $30 \%$ \\
\hline & & & $\begin{array}{l}\text { Proportion of positive and no } \\
\text { difference in number of section }\end{array}$ & $85 \%$ & $87 \%$ \\
\hline \multirow[t]{2}{*}{5} & \multirow{2}{*}{$\begin{array}{l}\text { Melia Hotel } \\
\text { International }\end{array}$} & \multirow[t]{2}{*}{ Tourism } & Total ADOT & -25 & -17 \\
\hline & & & $\begin{array}{l}\text { Proportion of positive } \\
\text { difference in number of section }\end{array}$ & $5 \%$ & $20 \%$ \\
\hline
\end{tabular}




\begin{tabular}{|c|c|c|c|c|c|}
\hline & & & $\begin{array}{l}\text { Proportion of positive and no } \\
\text { difference in number of section }\end{array}$ & $60 \%$ & $47 \%$ \\
\hline \multirow[t]{3}{*}{6} & \multirow{3}{*}{ Munich Airport } & \multirow[t]{3}{*}{ Transportation } & Total ADOT & +6 & +14 \\
\hline & & & $\begin{array}{l}\text { Proportion of positive } \\
\text { difference in number of section }\end{array}$ & $43 \%$ & $23 \%$ \\
\hline & & & $\begin{array}{l}\text { Proportion of positive and no } \\
\text { difference in number of section }\end{array}$ & $78 \%$ & $77 \%$ \\
\hline \multirow[t]{3}{*}{7} & \multirow[t]{3}{*}{ Novo Nordisk } & \multirow[t]{3}{*}{ Healthcare } & Total ADOT & -1 & +2 \\
\hline & & & $\begin{array}{l}\text { Proportion of positive } \\
\text { difference in number of section }\end{array}$ & $10 \%$ & $10 \%$ \\
\hline & & & $\begin{array}{l}\text { Proportion of positive and no } \\
\text { difference in number of section }\end{array}$ & $70 \%$ & $97 \%$ \\
\hline \multirow[t]{3}{*}{8} & \multirow[t]{3}{*}{ Royal BAM } & \multirow{3}{*}{$\begin{array}{l}\text { Construction } \\
\text { Services }\end{array}$} & Total ADOT & +1 & +36 \\
\hline & & & $\begin{array}{l}\text { Proportion of positive } \\
\text { difference in number of section }\end{array}$ & $13 \%$ & $43 \%$ \\
\hline & & & $\begin{array}{l}\text { Proportion of positive and no } \\
\text { difference in number of section }\end{array}$ & $80 \%$ & $100 \%$ \\
\hline \multirow[t]{3}{*}{9} & \multirow[t]{3}{*}{ Royal DSM } & \multirow{3}{*}{$\begin{array}{l}\text { Life and Material } \\
\text { Sciences }\end{array}$} & Total ADOT & -9 & +2 \\
\hline & & & $\begin{array}{l}\text { Proportion of positive } \\
\text { difference in number of section }\end{array}$ & $10 \%$ & $23 \%$ \\
\hline & & & $\begin{array}{l}\text { Proportion of positive and no } \\
\text { difference in number of section }\end{array}$ & $50 \%$ & $87 \%$ \\
\hline \multirow[t]{3}{*}{10} & \multirow[t]{3}{*}{ Uralsib } & \multirow[t]{3}{*}{ Financial Services } & Total ADOT & -28 & -11 \\
\hline & & & $\begin{array}{l}\text { Proportion of positive } \\
\text { difference in number of section }\end{array}$ & $0 \%$ & $0 \%$ \\
\hline & & & $\begin{array}{l}\text { Proportion of positive and no } \\
\text { difference in number of section }\end{array}$ & $58 \%$ & $63 \%$ \\
\hline
\end{tabular}

\section{CONCLUSION}

This study has found that in regards to integration, SEDs which matches with the GRI G3 guidelines do not appear in the main reporting. In earlier IR reports, sustainability of SED information is being reported into specific sections such as 'sustainability reports' and also mentions in the Chairman's statement. It can be seen that obvious deficiency of integration level of social and environmental information. Yet, most reports exhibited on SED were repeated with different phrasing and often exaggerated in the report. Therefore, it can be possibly justified that most of the companies' reports showing relatively less information of SED. On the other hand, the companies might have a limited knowledge about IR's approaches. Consequently, the companies are ambiguous as to exactly what an IR 'should' include and what it 'should' look like.

This study suggests that one way of improving SED in IR is to expand the information disclosed in the reports. Rather than merely repeating the same information in the reports, the way in which significant or material information is reported could be briefer, avoiding exaggerated repetition. Repeating important information in the report merely increases the quantity of social and environmental information and does not contribute an enhancement in the quality of reporting. Nonetheless, the integration of social and environmental information could be increased by a number of sections in the reports to improve non-financial information within the corporate reporting. More broadly, research is also needed to improve the quality of IR in relation to social and environmental information (all basic practices and policies) for companies to seek the views of their major stakeholders that they report; these views could be included within the reports - for example, major stakeholders' views in relation to the activities incorporated in IR, such as healthcare (diabetes, AIDS, HIV), employee training, climate change, waste reduction and biodiversity. In turn, these would improve the new dimension of IR that is currently lacking. Another recommendation is for IR to include an assurance statement by an independent 
assuror in order to ensure that social and environmental information disclosed is able to convince investors and other stakeholder groups. This can be done by hiring assurance practices in order to secure the information to be transparent and accountable to all stakeholders including environment and community. Fulfilling the legitimacy theory, the suggestions will help to manage the stakeholders needs as align to their interest, norms and beliefs.

The scope of this study was as the sample was too small and the study took place over a short period. The scope of companies can be changed by analysing companies that have a low-risk impact instead of high-risk impact industries, to measure the change in the risk impact of the IR establishment.

\section{ACKNOWLEDGEMENT}

This research thankfully recognizes the help of Universiti Malaysia Sarawak by giving Myra Special Short Term Grant Scheme under [F01/SpSTG/1576/2017].

Table 1 : GRI G3 Standard Reporting Guidelines: Social and Environment Section

\begin{tabular}{|c|c|}
\hline & $\begin{array}{c}\text { Core } \\
\text { Indicators }\end{array}$ \\
\hline \multicolumn{2}{|l|}{ Social } \\
\hline 1. Labour Practices and Decent Work & \\
\hline $\begin{array}{l}\text { 1.1. Aspect: Employment } \\
\text { - Total workforce by employment type, employment contract and region. } \\
\text { - Total number and rate of employee turnover by age group, gender and region. } \\
\text { - Benefits provided to full-time employees that are not provided to temporary or } \\
\text { part-time employees, by major operations. }\end{array}$ & $\begin{array}{l}\text { LA1 } \\
\text { LA2 } \\
\text { LA3 }\end{array}$ \\
\hline $\begin{array}{l}\text { 1.2 Aspect: Labour/Management Relations } \\
\text { - Percentage of employees covered by collective bargaining agreements. } \\
\text { - Minimum notice period(s) regarding operational changes, including whether it } \\
\text { is specified in collective agreements. }\end{array}$ & $\begin{array}{l}\text { LA4 } \\
\text { LA5 }\end{array}$ \\
\hline $\begin{array}{l}\text { 1.3 Aspect: Occupational Health and Safety } \\
\text { - Percentage of total workforce representing informal joint management worker } \\
\text { health and safety committees that help monitor and advise on occupational } \\
\text { health and safety programmes. } \\
\text { - Rates of injury, occupational diseases, lost days and absenteeism, as well as } \\
\text { number of work related fatalities by region. } \\
\text { - Education, training, counselling, prevention and risk control programmes in } \\
\text { place to assist workforce members, their families and community members } \\
\text { regarding serious diseases. } \\
\text { - Health and safety topics covered in formal agreements with trade unions. }\end{array}$ & $\begin{array}{l}\text { LA8 } \\
\text { LA9 }\end{array}$ \\
\hline $\begin{array}{l}\text { 1.4 Aspect: Training and Education } \\
\text { - Average hours of training per year per employee by employee category. } \\
\text { - Programmes for skills management and lifelong learning that support the } \\
\text { continued } \\
\text { employability of employees and assist them in managing career ends. } \\
\text { - Percentage of employees receiving regular performance and career } \\
\text { development reviews. }\end{array}$ & $\begin{array}{l}\text { LA } 10 \\
\text { LA11 } \\
\text { LA12 }\end{array}$ \\
\hline
\end{tabular}




\subsection{Aspect: Diversity and Equal Opportunity}

- Composition of governance bodies and breakdown of employees per category according to gender, age group, minority group membership and other indicators of diversity.

Ratio of basic salary of men to women by employee category.

\section{Human Rights}

\subsection{Aspect: Investment and Procurement Practices}

- Percentage and total number of significant investment agreements that include

HR1 human

rights clauses or have undergone human rights screening.

- Percentage of significant suppliers and contractors that have undergone screening on human rights and actions taken.

- Total hours of employee training on policies and procedures concerning aspects of human rights that are relevant to operations, including the percentage of employees trained.

\subsection{Aspect: Non-discrimination}

- Total number of incidents of discrimination and actions taken.

\subsection{Aspect: Freedom of Association and Collective Bargaining}

- Operations identified in which the right to exercise freedom of association and collective bargaining may be at significant risk, and actions taken to support these rights.

\subsection{Aspect: Child Labour}

- Operations identified as having significant risk for incidents of child labour and measures taken to contribute to the elimination of child labour.

\subsection{Aspect: Forced and Compulsory Labour}

- Operations identified as having significant risk for incidents of forced or compulsory labour, and measures to contribute to the elimination of forced or compulsory labour.

\subsection{Aspect: Security Practices}

- Percentage of security personnel trained in the organisation's policies or procedures concerning aspects of human rights relevant to operations.

\subsection{Aspect: Indigenous Rights}

- Total number of incidents of violations involving rights of indigenous people and actions taken.

\section{Society}

\subsection{Aspect: Community}

- Nature, scope, and effectiveness of any programmes and practices that assess and manage the impacts of operations on communities, including entering, 


\begin{tabular}{|c|c|}
\hline operating and exiting. & \\
\hline $\begin{array}{l}\text { 3.2 Aspect: Corruption } \\
\text { - Percentage and total number of business units analysed for risks related to } \\
\text { corruption. } \\
\text { - Percentage of employees trained in organisation's anti-corruption policies and } \\
\text { procedures. } \\
\text { - Actions taken in response to incidents of corruption. }\end{array}$ & $\begin{array}{l}\mathrm{SO} 2 \\
\mathrm{SO} 3 \\
\mathrm{SO} 4\end{array}$ \\
\hline $\begin{array}{l}\text { 3.3 Aspect: Public Policy } \\
\text { - Public policy positions and participation in public policy development and } \\
\text { lobbying. } \\
\text { - Total value of financial and in-kind contributions to political parties, } \\
\text { politicians, and related institutions by country. }\end{array}$ & $\begin{array}{l}\text { SO5 } \\
\text { SO6 }\end{array}$ \\
\hline $\begin{array}{l}\text { 3.4 Aspect: Anti-Competitive Behaviour } \\
\text { - Total numbers of legal actions for anti-competitive behaviour, anti-trust and } \\
\text { monopoly practices and their outcomes. }\end{array}$ & SO7 \\
\hline $\begin{array}{l}\text { 3.5 Aspect: Compliance } \\
\text { - Monetary value of significant fines and total number of non-monetary } \\
\text { sanctions for non-compliance with laws and regulations. }\end{array}$ & SO8 \\
\hline 4. Product Responsibility & \\
\hline $\begin{array}{l}\text { 4.1 Aspect: Customer Health and Safety } \\
\text { - Life cycle stages in which health and safety impacts of products and services } \\
\text { are } \\
\text { assessed for improvement, and percentage of significant products and services } \\
\text { categories subject to such procedures. } \\
\text { Total number of incidents of non-compliance with regulations and voluntary } \\
\text { codes concerning health and safety impacts of products and services during } \\
\text { their life cycles, by type of outcomes. }\end{array}$ & PR1 \\
\hline $\begin{array}{l}\text { 4.2 Aspect: Product and Service Labelling } \\
\text { - Type of product and service information required by procedures and } \\
\text { percentage of } \\
\text { significant products and services subject to such information requirements. } \\
\text { - Total number of incidents of non-compliance with regulations and voluntary } \\
\text { codes concerning product and service information and labelling, by type of } \\
\text { outcomes. } \\
\text { - Practices related to customer satisfaction, including results of surveys } \\
\text { measuring customer satisfaction. }\end{array}$ & $\begin{array}{l}\text { PR3 } \\
\text { PR4 } \\
\text { PR5 }\end{array}$ \\
\hline $\begin{array}{l}\text { 4.3 Aspect: Marketing Communications } \\
\text { - Programmes for adherence to laws, standards, and voluntary codes related to } \\
\text { marketing } \\
\text { communications, including advertising, promotion and sponsorship. } \\
\text { - Total number of incidents of non-compliance with regulations and voluntary } \\
\text { codes concerning marketing communications, including advertising, }\end{array}$ & $\begin{array}{l}\text { PR6 } \\
\text { PR7 }\end{array}$ \\
\hline
\end{tabular}




\begin{tabular}{|c|c|}
\hline \multicolumn{2}{|l|}{ promotion, and sponsorship by type of outcomes. } \\
\hline $\begin{array}{l}\text { 4.4 Aspect: Customer Privacy } \\
\text { - Total number of substantiated complaints regarding breaches of customer } \\
\text { privacy and losses of customer data. }\end{array}$ & PR8 \\
\hline $\begin{array}{l}\text { 4.5 Aspect: Compliance } \\
\text { - Monetary value of significant fines for non-compliance with laws and } \\
\text { regulations concerning the provision and use of products and services. }\end{array}$ & PR9 \\
\hline Environmental & \\
\hline $\begin{array}{l}\text { 1. Materials } \\
\text { - Materials used by weight or volume. } \\
\text { - Percentage of materials used that are recycled input materials. }\end{array}$ & $\begin{array}{l}\text { EN1 } \\
\text { EN2 }\end{array}$ \\
\hline $\begin{array}{l}\text { 2. Energy } \\
\text { - Direct energy consumption by primary energy source. } \\
\text { - Indirect energy consumption by primary source. } \\
\text { - Energy saved because of conservation and efficiency improvements. } \\
\text { - Initiatives to provide energy efficient or renewable energy-based products and } \\
\text { - } \text { services, and reductions in energy requirements as a result of these initiatives. } \\
\text { Initiatives to reduce indirect energy consumption and reductions achieved. }\end{array}$ & $\begin{array}{l}\text { EN3 } \\
\text { EN4 } \\
\text { EN5 } \\
\text { EN6 } \\
\text { EN7 }\end{array}$ \\
\hline $\begin{array}{l}\text { 3. Water } \\
\text { - Total water withdrawal by source. } \\
\text { - Water sources significantly affected by withdrawal of water. } \\
\text { - Percentage and total volume of water recycled and reused. }\end{array}$ & $\begin{array}{l}\text { EN8 } \\
\text { EN9 } \\
\text { EN10 }\end{array}$ \\
\hline $\begin{array}{l}\text { 4. Biodiversity } \\
\text { - Location and size of land owned, leased or managed in, or adjacent to, } \\
\text { protected areas } \\
\text { and areas of high biodiversity value outside protected areas. } \\
\text { - Description of significant impacts of activities, products and services on } \\
\text { biodiversity in protected areas and areas of high biodiversity value outside } \\
\text { protected areas. } \\
\text { - Habitats protected or restored. } \\
\text { - Strategies, current actions and future plans for managing impacts on } \\
\text { biodiversity. } \\
\text { Number of IUCN Red List species and national conservation list species with } \\
\text { habitats in areas affected by operations, by level of extinction risk. }\end{array}$ & $\begin{array}{l}\text { EN11 } \\
\text { EN12 } \\
\text { EN13 } \\
\text { EN14 }\end{array}$ \\
\hline $\begin{array}{l}\text { 5. Emissions, Effluents and Waste } \\
\text { - Total direct and indirect greenhouse gas emissions by weight. } \\
\text { - Other relevant indirect greenhouse gas emissions by weight. } \\
\text { - Initiatives to reduce greenhouse gas emissions and reductions achieved. } \\
\text { - Emissions of ozone-depleting substances by weight. } \\
\text { - NO, SO and other significant air emissions by type and weight. } \\
\text { Total water discharge by quality and destination. }\end{array}$ & $\begin{array}{l}\text { EN16 } \\
\text { EN17 } \\
\text { EN18 } \\
\text { EN19 } \\
\text { EN20 } \\
\text { EN21 }\end{array}$ \\
\hline
\end{tabular}


- Total weight of waste by type and disposal method.

EN22

- Total number and volume of significant spills.

- Weight of transported, imported, exported or treated waste deemed hazardous under the terms of the Basel Convention Annex I, II, III and VIII, and

EN24 percentage of transported waste shipped internationally.

- Identity, size, protected status and biodiversity value of water bodies and related habitats significantly affected by the reporting organisation's discharges of water and runoff.

\section{EN25}

6. Products and Services

- Initiatives to mitigate environmental impacts of products and services, and extent of impact mitigation.

- Percentage of products sold and their packaging materials reclaimed by category.

\section{Compliance}

- Monetary value of significant fines and total number of non-monetary sanctions for non-compliance with environmental laws and regulations.

\section{Transport}

- Significant environmental impacts of transporting products and other goods and materials used for the organisation's operations, and transporting members of the workforce.

\section{Overall}

- Total environmental protection expenditures and investments by type. 


\section{REFERENCES}

Adams, S. and Simnett, R., 2011. "Integrated Reporting: An Opportunity for Australia's Not- for-Profit Sector". Australian Accounting Review, Vol. 21 No. 3, pp. 292-301.

Archel, P., Husillos, J., Larrinaga, C. \& Spence, C., 2009. "Social disclosure, legitimacy theory and the role of the state", Accounting, Auditing \& Accountability Journal, 22 (8): 1284- 1307

Bebbington, J. and Gray, R., 2001. 'An Account of Sustainability: Failure, Success and a Reconceptualisation', Critical Perspectives on Accounting, 12: pp. 557-87.

Bebbington, J., Unerman, J. and O'Dwyer, B., 2014. Sustainability Accounting and Accountability. Oxon: Routledge.

Brown, J. and Dillard, J., 2014. "Integrated reporting: On the need for broadening out and opening up", Accounting, Auditing \& Accountability Journal, Vol. 27 No. 7, pp. 1120-1156.

Cheng, M., Green, W., Conradie, P., Konishi, N. and Romi, A., 2014. "The international integrated reporting framework: Key issues and future research opportunities", Journal of International Financial Management \& Accounting, Vol. 25 No. 1, pp. 90-119.

de Aguiar, T.R.S. and Bebbington, J., 2014. "Disclosure on climate change: Analysing the UK ETS effects", Accounting Forum 38: 227-240.

Deegan, C., Rankin, M. and Voight, P., 2000. 'Firm's Disclosure Reactions to Major Social Incidents : Australian Evidence', Accounting Forum, 24 (1): pp. 101-130.

Deegan, C., 2002. 'The Legitimising Effect of Social and Environmental Disclosures: A Thereotical Foundation', Accounting, Auditing \& Accountability Journal, 15(3), pp. 282- 311.

Deegan, C., 2007. ' Organizational Legitimacy as a Motive for Sustainability Reporting', in Unerman, J., Bebbington , J. and O'Dwyer, B. (eds.), Sustainability Accounting and Accountability (Abingdon : Routledge ) pp. 127-149.

de Villiers, C., Rinaldi, L. and Unerman, J., 2014. "Integrated Reporting: Insights, gaps and an agenda for future research", Accounting, Auditing \& Accountability Journal, Vol. 27 No. 7, pp. 1042 - 1067.

EY., 2014. EY's excellence in integrated reporting awards 2014: A survey of integrated reports from South Africa's top 100 JSE-listed companies and top 10 state-owned companies (Ernst \& Young Global Limited: London).

Flower, J., 2015."The International Integrated Reporting Council: A story of failure", Critical Perspectives on Accounting, Vol. 27 No. 1, pp. 1-17.

GRI, 2014. Global Reporting Resource Library. [online] Available at:

$<$ https://www.globalreporting.org/resourcelibrary/GRI-An-introduction-to-G4.pdf $>$ [Accessed 1st August 2015].

GRI, 2015. Global Reporting News. [online] Available at :

$<\underline{\text { https://www.globalreporting.org/information/events/conference2013/news/Pages/Up dates/1-2.aspx }>}$

[Accessed 12 ${ }^{\text {th }}$ August 2015]

Gomes, S. F., Eugénio, T. P., \& Branco, M. C., 2015. Sustainability reporting and assurance in Portugal. Corporate Governance: The International Journal of Business in Society, 15(3), pp. 281-292. 
Gray, R., Adams, C.A. and Owen, D., 2013. Accountability, Social Responsibility and Sustainability: Accounting for Society and the Environment. Harlow: Pearson.

IIRC. 2012. "The Pilot Programme Year Book 2013: Business and Investors Explore the Sustainability Perspective of Integrated Reporting", available at:

$<$ http://www.theiirc.org/wp-content/uploads/2013/12/IIRC-PP-Yearbook-

2013 PDF4 PAGES.pdf $>$ [accessed 14 August 2015].

IIRC, 2015. Integrated Reporting News. [online] Available at : $<\underline{\text { http://integratedreporting.org/news/only-10-of-companies-are-prepared-for-non- financial-reporting- }}$ directives-are-you/> [Accessed 10 July 2015]

Ioana, D., \& Adriana, T. T. ., 2013. New corporate reporting trends. Analysis on the evolution of integrated reporting. Annals of the University of Oradea, Economic Science

Series, 22(1), pp. 1221-1228.

Isaksson., R. and Steimle, U., 2009. "What does GRI-reporting tell us about corporate sustainability?", The TQM Journal, Vol. 21 Iss 2 pp. $168-181$

Kolk, A. and Perego, P., 2010. "Determinants of the adoption of sustainability assurance statements: an international investigation", Business Strategy and the Environment, Vol. 19 No. 3, pp. 182198.

Lodhia, S., 2014. "Exploring the transition to integrated reporting through a practice lens: An Australian customer owned bank perspective", Journal of Business Ethics.

Mathews, M. R., 2004. 'Developing a Matrix Approach to Categorise the Social and Environmental Accounting Research Literature', Qualitative Research in Accounting and Management, 1(1): p 30-35.

McNair-Connolly, C., Silvi, R. and Bartolini, M., 2013. "Integrated Reporting and Value-Based Cost Management: A Natural Union", in C. Busco, et al. (Eds.), Integrated Reporting (Springer International Publishing), pp. 147-157.

Merkl-Davies, D.M., Brennan, N.M. and Vourvachis, P., 2011. 'Text Analysis Methodologies in Corporate Narrative Reporting Research' (paper presented at 23rd CSEAR International Colloquium, St Andrews, September). pp. null.

Monfreda, C.M. Wackernagel, and D. Deumling., 2004. 'Establishing National Natural Capital Accounts Based On Detailed Ecological Footprint and Biological Capacity Assessments '. Land Use Policy 21.3: pp 231-246

Patten, D. M., 2014. Accounting for Public Interest. Advances in Business Ethics Research. Available at: link.springer.com <http://link.springer.co.uk> [Accessed 2 March 2015], pp. 201-215

Serafeim, G., 2014. "Integrated reporting and investor clientele", Harvard Business School Accounting \& Management Unit Working Paper, pp. 14-069.

Stubbs, W. and Higgins, C. (2014), "Integrated reporting and internal mechanisms of change", Accounting, Auditing \& Accountability Journal, Vol. 27 No. 7, pp. 1068 - 1089.

Unepfi, 2011. Unepfi publications . [online] Available at : $<$ http://www.unepfi.org/fileadmin/publications/property/Brief_Integrated_Reporti ng_Pilot_Programme3.pdf $>$ [Accessed $18^{\text {th }}$ August 2015].

Corresponding Author: Suzila Mohamed Yusof can be contacted at mysuzila@unimas.my 